\title{
O niilismo schopenhaueriano: uma introdução
}

\author{
Jarlee Salviano*
}

Resumo: Neste texto procuramos mostrar como se pode analisar o problema do niilismo na filosofia de Schopenhauer sem recorrer à interpretação nietzschiana - tendo em vista o peso e a importância dada por esta interpretação a este conceito dentro da filosofia e levando em conta principalmente que o termo não aparece em nenhum momento da obra schopehaueriana - tendo como pano de fundo a recepção do idealismo transcendental kantiano na Alemanha do final do século XVIII e início do XIX. Palavras-chave: niilismo - nada - Vontade - idealismo

O problema do niilismo acompanha às escondidas todo o desenvolvimento do pensamento schopenhaueriano. Antes de mostrar sua face nas últimas linhas de $O$ mundo como vontade e representação, o fantasma do nada já orientava os primeiros traços da pena do filósofo de Danzig. Ao verificarmos pois como esta problemática se aloja no edifício filosófico de Schopenhauer, cabe-nos erguer o cenário de nossa investigação, ou seja, é preciso aqui escutarmos o canto que embala a dança do niilismo na filosofia alemã do início do século XIX.

É lugar-comum entre os estudiosos do tema, que a preocupação com o Nada, o vazio de Ser, o Não-ser, apesar de ter seu nome filosófico registrado no final do século XVIII, tem a idade da própria Filosofia. De fato, não foi o Ser a única prole a descansar no berço da civilização ocidental: um outro rebento, o Não-ser, contemporâneo daquele, já clamava pela atenção dos primeiros sábios da antiga Hélade. Heidegger, por exemplo, perce-

\footnotetext{
${ }^{*}$ Mestrando do Departamento de Filosofia - FFLCH-USP e bolsista FAPESP.
} 
bera já nos Diálogos platônicos a presença oculta do niilismo (Cf. Pöggeler 3 , p. 308). Talvez não seja descabido também apontar esta presença nos versos oraculares do poema de Parmênides. Há ainda quem considere Górgias o primeiro niilista da história do Ocidente "pelo terrível raciocínio que nos legou: nada existe; se alguma coisa existisse, não a poderíamos conhecer; e, se a conhecêssemos, não seria comunicável (anhermèneuton)" (VOLPI 10, p. 9).

Ainda que o fenômeno do niilismo deite suas raízes em períodos remotos da história da filosofia, é no pós-kantianismo que ele começa a ser sistematicamente teorizado como discurso filosófico. É neste contexto que o conceito é usado pela primeira vez, por um lado para caracterizar a recepção da Crítica kantiana pelos idealistas e por outro para denunciar o quietismo decadente da primeira geração do Romantismo alemão. "Foi Jacobi", lembra-nos Paulo Arantes, "quem deu o tom a Nihilismusstreit em que se transformou a recepção do idealismo da nova filosofia alemã. Uma passagem célebre da Carta a Fichte de 1799 consta em todas as genealogias do niilismo moderno como a sua certidão de nascença: 'sinceramente, meu caro Fichte, não ficaria aborrecido se você, ou quem quer que seja, quiser chamar de quimerismo aquilo que eu oponho ao idealismo, que considero um niilismo"' (ARANTES 1, p. 243). No Idealismo, diz Jacobi numa outra passagem da Carta, "parte-se do nada, caminha-se para o nada, tem-se como meta o nada, está-se no nada" (Apud ARANTES 1, p. 244). Mais tarde o próprio Fichte fará uso do termo para caracterizar este processo do criticismo kantiano, levado ao extremo pela Doutrina-da-Ciência, em que a existência do mundo exterior é subordinada aos mecanismos do conhecimento.

A partir da epígrafe kantiana sob a qual "das coisas conhecemos a priori só o que nós mesmos colocamos nelas", tende-se a dissolver tudo aquilo que nos fenômenos não diz respeito à sua forma. Conseqüentemente, o mundo como ele é em si, para o conhecimento é nada. Resta-nos apenas o fugidio mundo como fenômeno. O kantismo, mormente em relação à sua recepção pelos pós-kantianos, surge assim como uma doutrina da "dissolução do referente", da "evaporação do mundo", devido à "recente elevação da filosofia à condição de 'ciência em si', uma bizarra ciência que tem a si mesma como objeto" (Idem 1, p. 245). Têm-se aí a origem da atmosfera niilista que envolvia a inteligência alemã na virada do século.

Pode-se mesmo afirmar que "nesta construção do real", que de certo modo representa o criticismo kantiano, "a coisa em si acaba reduzida ao 
nada e em última instância também se transforma em nada o próprio sujeito, já que toda sua realidade se reduz à de sua própria imaginação (Einbildungskraft) como produtora da objetividade" (CRAGNOLINI 2, p.16). A dissolução do referente, instigada pelo idealismo transcendental, ressoa também estridentemente na primeira geração do Romantismo alemão. Em 1804, Jean Paul critica nos primeiros românticos o fato de viverem "apenas celebrando o livre jogo da fantasia, ou seja, a atividade espontânea do eu criador, esquecendo o não-eu, a natureza toda, o universo inteiro, até mesmo Deus que acabam por anular" (Apud VOLPI 10, p. 21). Daí a um relativismo sofístico se estava a um passo.

Para Hegel, este niilismo dos intelectuais de sua época, que encontra em Fichte e nos românticos os seus principais representantes, era um niilismo incompleto, inacabado (cf. ARANTES 1, p. 245-6). Ele tomou para si a tarefa de organizar o niilismo: este espírito de negação, ou "espírito de contradição desgovernado" - para falar hegelianamente - tomava o nada como um fim e não como um meio, como ao contrário queria a Dialética de Hegel - definida por este, numa conversa com Goethe, como o "princípio de contradição organizado" - e para a qual o conhecimento do nada absoluto deve ser o ponto de partida da investigação filosófica, que, após sua superação (Aufhebung), deixa caminho livre para o conhecimento do Absoluto.

Cabe-nos agora verificar de que tipo é o niilismo schopenhaueriano e como ele se comporta diante dos niilismos que desfilavam neste início da Filosofia contemporânea: o primeiro (que podemos chamar de niilismo préhegeliano) em que se oferece apenas o desconsolo deixado pelo kantismo diante da idealidade da realidade fenomênica e da impenetrabilidade do mundo noumênico, é aquele no qual os representantes do primeiro Romantismo se inspiravam em seu descompromisso da negação assistemática, uma espécie de tatear cego do espírito; e o outro, o de Hegel - para quem o reconhecimento do nada absoluto deve ser a primeira tarefa da filosofia - pretende ser um niilismo completo, no qual a negação do finito deve ser apenas uma etapa preparatória para o conhecimento positivo do infinito, última tarefa da filosofia.

$\mathrm{Na}$ segunda fase do pensamento hegeliano, o termo niilismo dá lugar ao ceticismo, que ainda serve para indicar o conhecimento negativo que Hegel intenta transformar em método filosófico. Ademais, em todo o pensamento alemão a expressão parece ter entrado num estado de hibernação do qual despertará somente na segunda metade do século. Talvez isto expli- 
que a ausência do termo na filosofia schopenhaueriana, onde ele se faria tão adequado: numa filosofia, para empregar uma expressão usada pelo próprio Schopenhauer no Suplemento ao quarto livro de $O$ mundo como vontade e representação, em que a busca pelo paraíso perdido do não-ser ${ }^{1}$ figura-se como o objetivo principal do discurso especulativo. Retomando o fio da meada, estávamos a ponto de explicar que a crítica de Hegel ao "niilismo incompleto" (do tipo fichtiano) consiste em mostrar que, ali, o finito (fenômeno) é absolutizado no momento em que é apresentada a sua nulidade como a meta final da especulação filosófica, promovendo, conseqüentemente, a nadificação do infinito (Absoluto) para o conhecimento - efetivamente malograda, diga-se de passagem. Deste modo, este niilismo gira em torno de si mesmo sem sair do lugar: é uma negação que no final das contas não nega nada. Jacobi e Fichte não teriam percebido, segundo Hegel, que tanto o Nada como o ser-determinado são momentos da manifestação do Absoluto. O niilismo, ou ceticismo, diz Hegel, é a "vista (Einsicht) penetrante e consciente lançada na não-verdade do saber como fenômeno", ou seja, é o "lado negativo do conhecimento do absoluto" (Apud ARANTES 1, p. 251).

Não é difícil perceber o que há de comum nestas duas posturas: tanto em Hegel quanto em Fichte o niilismo é um fenômeno que ocorre no âmbito da razão pura, do Conceito; no limite, a negação aqui caracteriza uma trajetória do discurso especulativo, com a ressalva, no que diz respeito a Hegel, que a este momento deve-se seguir a conquista do Absoluto: a filosofia (discurso especulativo) "encerra em si mesma o negativo do ceticismo, o qual a ela não se contrapõe, nem se encontra fora dela, mas é um momento dela mesma que assim inclui o negativo em sua própria verdade" (Apud ARANTES 1, p. 251).

Isto posto, podemos então divisar no niilismo schopenhaueriano dois momentos: no primeiro a redução ao nada refere-se à postulação da idealidade do fenômeno: uma herança do kantismo que aproxima Schopenhauer do acomismo fichtiano e parece tornar sua filosofia uma indubitável referência para a observação da Carta de Jacobi. "O mundo é minha representação", lê-se no pórtico de sua obra principal. Nesta proposição esconde-se a tese de que o objeto do conhecimento não têm uma existência em si, mas é de certa forma uma criação do sujeito: "toda a causalidade e, por conseguinte, toda a matéria, toda a realidade, apenas existe pelo entendimento, para o entendimento, no entendimento" (Schopenhuer 8, $\mathrm{p}$. $19 ;$ e 4, p. 13$)^{2}$. 
Diante do que já vinha sendo dito nos seus dois escritos anteriores, esta sentença não traz em si nada de novo. Schopenhauer recita aqui a cartilha do idealismo transcendental kantiano. A novidade, ou como diria ele, o ponto em que sua filosofia provém da de Kant, "como de seu tronco" (Idem 6, p. 155; e 4, p.595), dá as caras no segundo livro de $O$ mundo como vontade e representação. Trata-se da intuição do mundo como Vontade, ou seja, Schopenhauer vê no mundo em si, no noumeno kantiano, no fundo metafísico do universo, não uma estrutura lógico-racional como o queria a metafísica clássica, mas um Ímpeto cego (Blinderdrang), uma força inconsciente da qual o mundo fenomênico é uma objetivação. É a partir desta descoberta que começa a ser aberta a clareira que leva ao Nada: é este o segundo momento do niilismo schopenhaueriano, do qual procuramos esboçar uma ligeira noção.

A preocupação com o problema do Nada - que definitivamente coloca Schopenhauer em cena como "mais um dos capítulos alemães do niilismo europeu" (ARANTES 1, p. 275) - só tem lugar no último parágrafo do quarto livro d'O mundo. Cabe-nos, então, percorrer o espinhoso caminho que leva até ele, procurando verificar se o espirito de negação aqui consegue superar ou não o niilismo incompleto a que se dirige a crítica de Hegel e cuja presença já se fez notar nesta parte da análise do pensamento schopenhaueriano.

Antes disto, faz-se necessário a observação de que ao contrário do que se possa pensar, o pessimismo, expressão que indica o lado, digamos, popular da recepção do pensamento de Schopenhauer, não se confunde com o conceito do niilismo com o qual nos entretemos aqui. A constatação do fato da irrecuperável miséria da condição humana, o apelo à aceitação tranqüila da absoluta falta de saída para o sofrimento e o tédio aos quais tendem inevitavelmente nossas ações, que caracterizam este aspecto quase jornalístico de seu pensamento, talvez possa ser encarado como uma conseqüência natural - para não dizer lógica - da concepção do mundo como Vontade. O raciocínio que condena a existência humana ao infortúnio é desconsoladamente simples: O mundo é Vontade; Vontade representa carência; e carência é sempre sofrimento. Na felicidade não há nada de positivo, ela é o negativo da vida, uma exceção rara; e o otimismo chega a ser mesmo uma ofensa, a vida "é um estado de infelicidade radical" (Schopenhauer 8, p. 427; e 4, p. 381). Conquanto a satisfação ponha fim ao querer, conclui o autor d' $O$ mundo, 
"para cada desejo satisfeito, dez permanecem irrealizados. Além disto, o desejo é duradouro, as exigências se prolongam ao infinito; a satisfação é curta e de medida escassa. O contentamento finito, inclusive, é somente aparente: o desejo, imediatamente dá lugar a um outro; aquele já é uma ilusão conhecida, este ainda não. Satisfação duradoura e permanente objeto algum do querer pode fornecer; é como uma caridade oferecida a um mendigo, a lhe garantir a vida hoje e prolongar sua miséria ao amanhã. Por isto, enquanto nossa consciência é preenchida pela nossa vontade, enquanto submetidos à pressão dos desejos, com suas esperanças e temores, enquanto somos sujeitos do querer, não possuiremos bem-estar nem repouso permanente. Caçar ou fugir, temer desgraças ou perseguir o prazer, é essencialmente a mesma coisa; a preocupação quanto à vontade sempre exigente, seja qual for a forma em que o faz, preenche e impulsiona constantemente a consciência; sem repouso porém não é possível qualquer bem-estar" (Schopenhauer 9, p. 26; e 4, p. 230-1) $)^{3}$.

Para os que viram nestas linhas, horrorizados, o rascunho do mapa do inferno, que seja perdoada a ironia: pode-se dizer que não viram nada! De fato o nada ainda está por vir. O pessimismo em Schopenhauer é a introdução ao niilismo. É na busca pela saída do infortúnio - busca que representa um momento, dirão alguns, demasiado feliz da senda especulativa do filósofo - na procura do tão escondido Eldorado da Ataraxia estóica, enfim, no desespero pela ausência de consolo (Trost) (Idem 7, p. 424; e 5, p 1421) que presenciaremos o advento de uma redução ao nada talvez inusitada na história do conceito tematizado em nossa investigação. Só há uma saída, dirá Schopenhauer, é preciso cortar o mal pela raiz: é preciso negar a nossa própria essência, a Vontade, causa de todo o sofrimento no mundo.

Ora, Vontade e Vida (ou Vontade de viver - Wille zum Leben) são sinônimos para Schopenhauer: esta é uma melodia conhecida de qualquer nietzchiano e que nos leva a concluir, paradoxalmente, que a solução para a vida é a negação da vida, ou da Vontade de viver. Ei-nos aqui, talvez como já era esperado, diante do problema do suicídio. Seria este o descanso do espírito, prometido ainda há pouco? (A suspeita de tal assertiva se torna tão mais evidente quanto nos lembramos que Schopenhauer coloca em par de igualdade a afirmação da Vontade com a afirmação do corpo, donde se conclui que a negação dela deve ser também a negação do corpo). Tentativa 
malograda - diria o filósofo - o suicídio não resolve o problema pois a vontade, da qual o corpo do indivíduo é apenas o fenômeno visível, permanece inalterada segundo ele, mesmo com o perecimento do corpo; a vida não é um espaço entre dois nadas: nascimento e morte são conceitos que, para Schopenhauer, só fazem sentido no mundo como representação. E se a causa do sofrimento não desaparece, conclui, o sofrimento também não:

"Se o suicídio nos assegurasse o nada, se na verdade nos fosse proposta a alternativa 'de ser ou não ser', então sim seria preciso escolher o não ser, e isso seria um desenlance digno de todos os nossos desejos. Só que, em nós qualquer coisa nos diz que não é nada assim: que o suicídio não desenlança nada, que a morte não é um aniquilamento (Vernichtung) absoluto" (Idem 8, p. 429; e 4, p. 383).

Além do mais, o suicida não nega a Vontade, a vida, como parece, mas nega os obstáculos que se erguem contra a sua vontade. Em última instância trata-se de uma manifestação extremada do querer, de afirmação da vida.

Vejamos o assunto de forma mais esquemática: como nos é conhecido desde o segundo livro d'O mundo, o homem, como todo o universo, é essencialmente Vontade. O corpo nada mais é que o fenômeno, a objetivação imediata da vontade individual (a Idéia platônica) que constitui a essência do homem e a qual Schopenhauer chama de caráter. No limiar do quarto e último livro será feita uma divisão em três formas de manifestação do caráter: o caráter inteligivel, que é a vontade individual propriamente dita, fora do tempo e do espaço; o caráter empírico ou manifestação no tempo do primeiro, que se dá através da conduta humana; e finalmente o caráter adquirido, mencionado rapidamente por Schopenhauer sem lhe ser dado grande importância: trata-se do caráter "que se forma na vida prática do mundo" (Idem 8, p. 400; e 4, p. 357). Os primeiros são inalteráveis. O caráter inteligível se dá fora do tempo portanto é alheio à mudança, como o caráter empírico que é apenas a manifestação daquele ${ }^{4}$. É por esta razão que o filósofo afirma que a ética não molda o indivíduo, não forma virtuosos, como a estética não forma gênios(Idem 8, p. 358; e 4, p. 320).

O que realmente muda em relação ao caráter é apenas a sua direção, provocada pela força dos motivos, nunca o que ele é essencialmente em si. 
Mesmo o nascimento e a morte são fenômenos que ocorrem totalmente à margem da essência do indivíduo ${ }^{5}$. Esta questão será retomada mais adiante. Por ora, cabe-nos guardar que toda atitude humana tem por trás de si o gerenciamento desta força cega, ou seja, só tem sentido enquanto manifestação da Vontade. A totalidade dos tipos destas atitudes se deixa captar de modo fácil - são efetivamente quatro: 1) a afirmação (Bejahnung) cega da Vontade, em que o intelecto é totalmente submisso a esta, não podendo reconhecer o mundo como é em si, mas apenas objetos para a satisfação do querer, em que, portanto, as coisas se mostram meramente como motivos; 2) o autoconhecimento (Selbsterkenntniß) da Vontade, apanágio do homem, em que o intelecto se rebela contra o seu algoz e da qual temos um exemplo no terceiro livro de sua obra mestra através do conhecimento estético; e finalmente as duas atitudes que derivam daí: 3)a afirmação consciente da Vontade, e 4) a negação desta.

A afirmação consciente da Vontade ocorre "quando, na sua manifestação, no mundo e na vida, ela vê a sua própria essência representada a si mesma com plena clareza, esta descoberta não pára de modo nenhum o seu querer: ela continua todavia a querer esta vida cujo mistério se desvenda assim perante si, já não como no passado, sem se dar conta, e através de um desejo cego, mas com conhecimento, consciência, reflexão (besonnen)" (Idem 8, p. 375; e 4, p. 336) ${ }^{6}$. As expressões da afirmação da vontade no corpo são a conservação do indivíduo e a propagação da espécie, tendo nos órgãos genitais o seu verdadeiro foco.

No fenômeno da negação "a vontade cessa, deixando as aparências individuais, uma vez conhecidas como tais, de serem motivos" (Idem 8, 375; e 4, p. 336).

Encontramo-nos, deste modo, mais uma vez com o niilismo schopenhaueriano, agora com nova roupagem: a nadificação aqui, para usar o neologismo sartriano, não se dirige apenas a realidade fenomênica, ao finito (como se vê em Fichte), mas parece direcionar-se à própria raiz metafísica do mundo. Eis algo tão inusitado até mesmo para o niilismo acabado de Hegel. Estaríamos então presenciando uma condenação ao nada absoluto do próprio Ser? A existência encontraria aí o seu vácuo infinito?

Antes de atentarmos para a resposta do próprio Schopenhauer, tentemos entender melhor este estado de conversão no qual é suprimido (Aufhebt) o "ser que serve de base ao fenômeno" (Idem 8, 380; e 4, 339), em que "a própria essência do nosso ser suprime-se" (Idem 8, p. 397; e 4, p. 355). 
No percurso entre o autoconhecimento da Vontade e a sua negação, Schopenhauer apresenta alguns exemplos de afirmação com consciência da Vontade em que, assim como na negação, há a libertação (ainda que imperfeita e temporária) do princípio de individuação e do egoísmo, numa palavra: em que o sujeito do conhecimento enxerga para além do Véu de Maya. Nas assim chamadas acões virtuosas há uma "passagem momentânea" ao ponto de Negation da Vontade: são elas a justiça, a bondade e a caridade (ou compaixão). Estas três manifestações prévias à negação completa da Vontade - pode-se dizer também que são formas imperfeitas de negação, pois ainda apresenta alguns resquícios de afirmação da Vontade - estão dispostas pelo filósofo hierarquicamente de acordo com a força da intuição capaz de elevar-se para além do principio individuationis. Assim, o justo reconhecendo no outro a mesma essência que a sua percebe que fazer mal ao outro é fazer mal a si mesmo e se detém, não invade o domínio do outro na busca de satisfação própria (como o faz o injusto), "vê que a distinção entre o indivíduo que faz o mal e aquele que o sofre é uma pura aparência que não atinge a coisa em si, que esta, a Vontade, está ao mesmo tempo viva em ambos (...) Na sua violência, ela enterra os dentes na sua própria carne, sem ver que é ainda a si que se rasga" (Idem 8, p. 470; e 4, p. 418). O bondoso, ou para ser fiel a Schopenhauer, o sujeito dotado de amor pela humanidade (Menschenliebe), ultrapassa a ação justa através do reconhecimento de que o bem de todos é também o seu próprio bem, atingindo assim uma serenidade de espírito ainda maior. Enfim, o último passo, apresentado no quarto livro, antes da ataraxia completa da negação da vontade, encontra-se na caridade (Liebe) ou compaixão (mitleid), em que o véu de Maya é ultrapassado por um olhar ainda mais penetrante, e em que o sujeito sente que as dores do mundo são também as suas dores. Neste estado ele "impõese privações a fim de aligeirar os males do outro" (Idem 8, 494-5; e 4, p. 440), pois já não vê diferença entre ele e o outro.

Chega-se então àquilo que Schopenhauer chamará de Summun bonum: a negação da vontade, a redução ao nada, "o remédio radical e único para a doença, enquanto que todos os outros bens são puro paliativos, simples calmantes" (Idem 8, p. 481; e 4, p. 428). Este estado de não-querer tem um nome: ascetismo ${ }^{7}$. Ocorre aqui uma conversão radical do sujeito que conhece. $\mathrm{O}$ autoconhecimento não leva a uma afirmação da vontade; o asceta não só reconhece como suas as dores alheias e é tomado de compaixão mas é levado a um completo abandono de si mesmo, à uma negação de 
sua própria essência, a um estado em que a Vontade, diz o filósofo, foi suprimida: o asceta

"percebe o conjunto das coisas, conhece-lhes a essência, e vê que ela consiste num escoamento perpétuo, num esforço estéril, numa contradição íntima, e num sofrimento contínuo; e ele vê que é a isso que estão votados, a miséria humana e a miséria animal, e, enfim, um universo que se dissipa sem cessar (...) Então a vontade desliga-se da vida: ela vê nos prazeres uma afirmação da vida, e tem horror deles. O homem chega ao estado de abnegação voluntária, de resignação, de calma verdadeira e de paragem absoluta do querer (Willenlosigkeit) (Idem 8 , p. 503-4; e 4, p. 448) (...) eles amam os seus sofrimentos e a sua morte, visto que entraram na negação do querer-viver, muitas vezes recusam mesmo a salvação que se lhes oferece e morrem voluntariamente, com tranqüilidade e felicidade" (Idem 8, p. 522; e 4, p. 465).

Deixando de lado a estranheza causada pela proposta de uma ataraxia tão dificilmente exeqüível, observaremos que Schopenhauer estabelece ainda quatro etapas em que o processo do ascetismo se desenvolve : 1) A castidade; 2) Pobreza voluntária; 3) Aceitação do sofrimento, casual ou provocado por outrem; e 4) Mortificação do corpo: que não pode ser ativa, violenta, como no suicídio vulgar mas deve ser passiva, uma espécie de inanição (como a despreocupação com a alimentação por exemplo). Enquanto o suicida, por não conseguir deixar de querer, deixa de viver, o asceta por outro lado, afirma Schopenhauer, "deixa de viver apenas porque deixou completamente de querer" (Idem 8, p. 531; e 4, p. 474).

A suspeita levantada há pouco aparentemente ganha aqui uma confirmação incontestável: o pensamento schopenhaueriano parece mesmo atinar com o Nada absoluto; não como aquele abrigado no seio do Absoluto hegeliano, etapa intermediária, negativa, mas, ao que tudo indica, trata-se de um Nada impensável, absurdo, um limbo do pensamento, situado à margem das fronteiras do Ser, pois não se trata mais aqui apenas da nulidade do fenômeno, a negação agora se dirige à Vontade, à essência mesma de todas as coisas. No sujeito no estado de não-querer, diz Schopenhauer:

"A morte não põe só, como nos outros, termo à manifestação da vontade: a própria essência [desta] é suprimida, visto que o último res- 
to de existência que lhe restava ligava-se a essa manifestação e a morte quebra esta frágil [linha (Band)]. Para aquele que acaba assim, o universo acaba ao mesmo tempo" (Idem 8, p. 508; e 4, p. 452).

Esta tese não é contudo tão fácil de ser assimilada e tampouco de ser defendida. Sabemos da impossibilidade de pensar, no interior do pensamento de Schopenhauer, num ponto do universo onde a Vontade não se faça presente - afinal de contas o universo inteiro é Vontade. Muito menos é permitida uma espécie de hecatombe da Vontade, um holocausto em que o universo inteiro se engole a si mesmo numa espécie de buraco negro infinito. Assim como, definitivamente, não é possível imaginar uma espécie de bigbang da Vontade, um nascimento ex nihil da raiz metafísica do universo: o antes e o depois é impensável no âmbito da Coisa em si: o tempo é uma ilusão do fenômeno, só existe, como já ressaltamos, para o sujeito que conhece. $\mathrm{O}$ intelecto não pode sequer ter um conhecimento positivo, direto da Vontade. Ao contrário o contato com ela é sempre indireto, através da intuição voltada para o interior do próprio sujeito cognoscente, que vê ali a manifestação mais imediata da realidade noumênica: a vontade individual.

E se, por outro lado, defendêssemos que esta negação, ao invés de se dirigir à Vontade como Coisa em si, na verdade representasse apenas a nulidade desta vontade individual, numa palavra, se se tratasse apenas da supressão do caráter ${ }^{7}$ As passagens que aludem para uma tal hipótese não são escassas:

"O caráter nunca pode modificar-se parcialmente; ele tem que com o rigor duma lei natural, executar em pormenor as ordens da vontade de que ele é o fenômeno de conjunto, mas o próprio conjunto, isto é, o caráter, pode ser completamente suprimido (aufgehoben) pela conversão do conhecimento (Veränderung der Erkenntniß)." (Idem 8, p. 534; e 4, p. 477) ${ }^{9}$.

A nossa investigação teria aqui a sua conclusão satisfatória se não fosse preciso repetir a censura feita acima, agora em relação ao caráter, à vontade individual: a negação aqui, novamente, não é nenhuma redução ao nada absoluto. No fenômeno da negação da Vontade, o caráter não desaparece do seu fenômeno como se evaporasse deixando para trás um corpo sem 
vida, sem vontade, sem essência. Se assim fosse, toda a discussão sobre a morte - a musa inspiradora da filosofia (Idem 7, p. 273; e 5, p. 1240) - que abre o livro IV e também os Suplementos a este livro, estaria sendo contradita. Já vimos que, para Schopenhauer, a vontade no indivíduo é a base metafísica imutável e imperecível sobre a qual se assenta a sua objetivação adequada, o corpo. Este pode ser suprimido, aquela nunca ${ }^{10}$ - entretanto, não podemos nos esquecer de medirmos a distância que separa este argumento sobre a nossa essência eterna e as concepções antigas sobre a psiquê, a anima, ou alma pensante: o conhecimento é, para Schopenhauer, uma atividade cerebral, o cérebro é sinônimo de intelecto, e este perece necessariamente com o corpo. Esta outra passagem torna mais evidente a confirmação da impossibilidade da negação absoluta do caráter:

"É precisamente porque se trata aqui, não duma mudança do caráter, mas duma supressão (Aufhebung) total, que se compreende por que os caracteres que diferiam muito antes desta supressão, apresentam, depois desta supressão, uma grande similitude na sua maneira de agir, continuando, cada um segundo os seus conceitos e os seus dogmas, a ter uma linguagem diferente" (Idem 8, p. 535; e 4, p. 477-8) ${ }^{11}$.

Eis o flagrante: que tipo de supressão, aniquilamento, negação, etc., ainda deixa depois de si intacta a coisa negada? Não parece fácil encontrarmos este algo que é suprimido nesta negação.

Chegado a este ponto, como compreender definitivamente esta negação da Vontade, este estado de não-querer, esta nulidade (Nichtigkeit) da Vontade, etc., sem contradizermos aqueles princípios mais elementares da metafísica schopenhaueriana? O próprio filósofo de Danzig compreendeu a enrrascada em que estava se metendo e, antes de descansar sua pena na execução d'O mundo como vontade e representação, no último parágrafo, enfrenta de frente o problema:

"Uma vez conduzidos, pelas nossas especulações, a ver a santidade perfeita na negação e no sacrifício de todo o querer, uma vez libertados, graças à conviçção, de um mundo cuja [existência (Daseyn)] total se reduz para nós à dor, a última palavra da sabedoria consiste, para nós, daqui em diante, apenas em nos afundarmos no nada (in das leere Nichts)" (Idem 8, p. 542; e 4, p. 483). 
No entanto, o conceito do nada, revela-nos ainda este parágrafo, é para Schopenhauer essencialmente relativo. Refere-se sempre, em última instância, à falta de um objeto determinado do qual é a sua negação. A negação da Vontade schopenhaueriana não leva à um nada absoluto, ou como nos diz o filósofo, um nada em todos os sentidos (Idem 7, p. 292; e 5, p. 1263). A partir da distinção kantiana - apresentada de forma incompleta naqueles últimos instantes de sua obra mestra ${ }^{12}$ - entre nihil privativum (nada relativo) e nihil negativum (nada absoluto) entendido como uma espécie de contradição lógica que se destrói a si mesma, Schopenhauer conclui que

"Se observarmos de mais perto, não existe nenhum nada absoluto; o nihil negativum propriamente dito não existe, não é uma noção pensável. Todo o nada deste gênero desde que o consideremos sob um ponto de vista mais elevado, desde que se subsuma sob um conceito mais extenso, não pode deixar de se reduzir ao nihil privativum. Todo o nada é qualificado de nada apenas em relação a uma outra coisa (...) a própria contradição lógica é apenas um nada relativo. É uma coisa que a razão não pode pensar, mas não se segue por isso que seja um nada absoluto" (Idem 8, p. 542-3; e 4, p. 484).

Deste modo, no niilismo schopenhaueriano, a negação, no fundo, não é negação no sentido forte do termo, não mais que no niilismo fichtiano. Afinal de contas, o sujeito que opera a negação ainda permanece, agora como Sujeito Puro do conhecimento; O mundo como Vontade também não é atingido nem de raspão. A única coisa a ser aniquilada é justamente o mundo como fenômeno: mas como lamentar a sua nulidade se já sabíamos de antemão que ele era uma ilusão, um Véu de Maya, que já era, portanto, um nada? Como chorar a nadificação do Nada? A partir daí um sem-número de conclusões poderiam ser tiradas. Por exemplo, no mundo como Vontade a causalidade, o espaço e o tempo são nada; para o sujeito que conhece através do princípio de individuação, ao contrário, é o mundo como Vontade é que é o nada; e assim por diante.

Mas a principal conclusão a ser extraída dali e, se estiver correta, tocamos na espinha dorsal do niilismo schopenhaueriano, é a de que, no limite, a redução ao nada ali representa tão somente uma modificação do modo de funcionamento do aparelho cognitivo, uma revolução provocada por si mesmo no intelecto, ou ainda, para usar a expressão de uma passagem su- 
pra citada, trata-se de uma conversão do conhecimento - o que nos deixa tentados a ver nos termos Veränderung e Wendung, igualmente traduzidos por conversão (usados algumas poucas vezes por Schopenhauer para se referir ao fenômeno da negação da Vontade) uma precisão muito maior na representação de sua niilização ${ }^{13}$ do que os termos Verneinung, Verschwinden ou mesmo o Aufhebung.

Para falar com justeza, esta conversão se refere em última instância à relação entre o intelecto e a vontade, em que aquele não é mais subjugado por esta, funciona à sua revelia, não mais se ocupando em ser um instrumento para a sua satisfação. Forma-se então uma contradição entre a vontade e sua forma visível: o corpo nega o que a vontade quer, ou seja, a própria vida. O sujeito cognoscente torna-se assim, como é sabido, um Sujeito puro do conhecimento, de posse da tão sonhada Ataraxia estóica e imune ao sofrimento e ao tédio. O santo e o monge no estado do Nirvana são, para o filósofo, exemplos deste estado de não-querer: na santidade, o conhecimento não percebe mais nas coisas qualquer relação com a Vontade; sem a determinação desta, concebe-se as coisas como elas são em si, a representação não é mais produzida pelo intelecto. $\mathrm{O}$ mundo fenomênico, diria Schopenhauer ( agora a asserção não nos assusta tanto), este mundo, dizíamos, perdeu-se no nada.

À filosofia cabe apenas, abstratamente, através de conceitos, reproduzir esta experiência:

"Se, contudo, fosse preciso, a qualquer preço, dar uma idéia positiva daquilo que a filosofia apenas pode exprimir dum modo negativo, chamando-lhe negação da Vontade, não haveria outro meio senão reportarmo-nos àquilo que experimentam aqueles que chegaram a uma negação completa da vontade, àquilo a que se chama êxtase, arrebatamento, iluminação, união com Deus, etc., mas, para falar a verdade, não se poderia dar a esse estado o nome de conhecimento, visto que ele já não comporta a forma de objeto e sujeito e, aliás, pertence apenas à experiência pessoal; é impossível comunicar exteriormente a sua experiência (Erfahrung) a outrem" (Idem 8, p. 544; e 4, p. 485) ${ }^{14}$.

Sem demora, podemos concluir - certamente sem o receio do início - conforme as últimas p[alavras de $O$ mundo como vontade e representação, que "para aqueles a quem a Vontade anima, aquilo que resta, após a 
supressão total da Vontade, é efetivamente o nada. Mas, ao contrário, para aqueles que se converteram e aboliram a Vontade, é o nosso mundo atual, este mundo tão real com todos os seus sóis e todas as suas vias lácteas, que é o nada" (Idem 8, p. 546; e 4, p. 487).

\begin{abstract}
In this text one search to show how one can analyze the problem of nihilism in Schopenhauer's Philosophy without resorting to Nietzsche's Interpretation having in mind the weight and the importance given by this interpretation to this concept in the philosophy and take into consideration mostly that the term does not appear on no moment of the work of Schopenhauer - having as background the reception of Kant's transcendental idealism in Germany in the end of the XVIII century and beginning of the XIX.

Key-words: nihilism - nothingness - Will - Idealism
\end{abstract}

\title{
Notas
}

${ }^{1}$ Verlorenen Paradiese des Nichtseyns. Suplemento IV, p. 277 (Félix Alcan) p. 1245 (Ausgabe).

${ }^{2}$ A parte grifada (por minha conta), foi suprimida na tradução da Rés-Porto.

${ }^{3}$ Schopenhauer chega a identificar o dia de Domingo com o tédio ou aborrecimento, e os demais com a dor e a necessidade (Idem 8, p. 414; e 4, p. 370), sendo assim, "a vida oscila, como um pêndulo, da direita para a esquerda, do sofrimento para o tédio (Idem 8, p. 411; e 4, p. 369). "A própria vida é um mar cheio de escolhos e redemoinhos” (Idem 8, p. 413; e 4, p. 369).

${ }^{4}$ Conforme a máxima de Sêneca tomada emblematicamente por Schopenhauer para traduzir esta tese: Velle non discitur (Idem 8, p. 388; e 4, p. 347).

5 "Não existe mais o braço potente que retesava, há três mil anos, o arco de Ulisses; mas um espírito prudente e que sabe refletir irá crer por isto na destruição total da força que agia com tanta energia neste braço?" (Idem 7, p. 281; e 5, p. 1250).

${ }^{6}$ No entanto, esta Besonnenheit (clareza de consciência, circunspecção ou reflexão) elemento sem o qual não é possível o autoconhecimento - conseqüentemen- 
te nem a afirmação ou mesmo a negação do querer - não pode ser pensada como pertencente ao âmbito do conhecimento abstrato: embora autoconhecimento, afirmação e negação derivem do conhecimento, este conhecimento é essencialmente intuitivo, portanto é obra do intelecto e não da razão, do pensamento, do conhecimento especulativo.

7 "Pela palavra ascetismo (...) entendo rigorosamente, o aniquilamento refletido (vorsätliche) do querer que se obtém pela renúncia dos prazeres e pela procura do sofrimento; entendo um penitência voluntária, uma espécie de punição que a pessoa se inflige para chegar à mortificação da vontade”. (Idem 8, p. 520; e 4, p. 463).

8 "O caráter é suprimido na negação da Vontade". (Idem 7, p. 421; e 5, p. 1418).

${ }^{9}$ Numa infelicidade sem tamanho a tradução da Rés traduz a frase por mim grifada por "conversão da vontade".

${ }^{10}$ É neste sentido que Schopenhauer fala da "eternidade (Unvergänglichkeit) de nossa essência”.(Idem 7, p. 282; e 5, p. 1251).

${ }^{11}$ Meu itálico.

${ }^{12}$ Para Kant o conceito de nada deve ser dividido em quatro partes, de acordo com a disposição da tábua das categorias do entendimento. Assim, temos o nada enquanto "objeto de um conceito para o qual não se pode obter absolutamente nenhuma intuição correspondente, isto é, um conceito sem objeto", denominado ens rationis. Temos como exemplo deste tipo de nada o noumeno. Em segundo lugar, o "conceito da falta de um objeto, como a sombra, o frio" nos revela o nada enquanto nihil privativum. A intuição vazia sem objeto, como espaço e tempo puros, representam o nada como ens imaginarium. E finalmente, o objeto de um conceito que guarda contradição que acaba por se reduzir à um nada absoluto: o nihil negativum (como, por exemplo, a idéia de um polígono retilíneo). KANT, I. Crítica da razão pura. Trad. Valerio Rohden e Udo Moosburger. 3 ed. São Paulo: Nova Cultural, 1987 (Os Pensadores, v. 1).p. 171

${ }^{13}$ A neologismo pode ser encontrado na tese de Mónica Cragnoli, Nietzsche, camino y demora, p. 45.

${ }^{14}$ Desafortunadamente a expressão por mim grifada foi traduzida pela Rés como "Idéia", o que torna a passagem citada, tendo em vista o peso deste conceito no âmbito do pensamento schopenhaueriano, extremamente problemática. 


\section{Referências Bibliográficas}

1. ARANTES, Paulo Eduardo. Ressentimento da dialética: dialética e experiência intelectual em Hegel: antigos estudos sobre o ABC da miséria alemã. Rio de Janeiro: Paz e terra, 1996.

2. CRAGNOLI, Mónica. Nietzsche, camino e demora. La Plata: Ed. Universitaria de La Plata, 1998.

3. SCHOPENHAUER, Arthur. Sämtliche Werke, 7 Bände. Wiesbanden, F. A. Brockhaus, 1972. Edição de Arthur Hübscher.

4. PÖGGELER, Otto. Hegel und die Anfänge der Nihilismus-disckussion. In: Der Nihilismus als Phänomen der Geistsgeschichte, Dieter Arendt (org.), Darmstadt, Wissenchaftliche Buchgesellschaft, 1974.

5._. Sämtliche Werke in fünf Bände. Grossherzog Wilhelm Ernst Ausgabe. Leipzig, s/d.

6. Crítica da filosofia Kantiana. Trad. Maria Lúcia Mello e Oliveira Cacciola. São Paulo: Abril Cultural, 1980 (Os Pensadores).

7. Le monde comme volonté e comme représentation. Suplementos. Trad. A. Burdeau. Paris: Félix Alcan, s/d.

8. __ O mundo como vontade e representação. Trad. M. F. Sá Correia. Porto: Editora Rés, s/d.

9. __ O mundo como vontade e representação, Livro III. Trad. Volfgang Leo Maar. São Paulo: Abril Cultural, 1980. (Os Pensadores)

10. VOLPI, Franco. O niilismo. Trad. Aldo Vannucchi. São Paulo: Edições Loyola, 1999. 
